\title{
ACUTE PHASE RESPONSE IN WISTAR RATS AFTER CONTROLLED HEMORRHAGE
}

\author{
STEPANOVIĆ P*, MALIČEVIĆ Ž Ž*, ANDRIĆ N* and NIKOLOVSKI STEFANOVIĆ ZORICA* \\ *University of Belgrade, Faculty of Veterinary Medicine, Serbia \\ **Military Medical Academy, Institute for Medical Research, Belgrade,Serbia \\ (Received 22 ${ }^{\text {nd }}$ December 2010)
}

After injury the acute-phase response of the organism activates mechanisms which imply the release of cytokines, stress hormones, and mediators of pain and inflammation. The main function of the acutephase response is to hinder further damage of the injured tissue by activating reparative processes. The increase in the concentration of acute phase proteins and the concurrent decrease in albumins and prealbumins indicate that there is a strong link between the liver and the traumatized site. Considering bleeding to be a major injury it can be supposed that it can result in changes in acute phase proteins concentrations despite the fact that it is not directly related to inflammatory reactions.

In order to confirm this presumption the concentration changes in negative and positive acute phase proteins in Wistar rats' blood plasma were measured during a 10 day period after controlled bleeding. The result of the therapeutic effects of transfusion on acute phase proteins was estimated in a group of rats in the so called "hospital stage" at which the blood loss was recovered by citrate blood transfusions. At the end of the 10th day the rats were monitored for an additional 10 day period.

The obtained results confirm that bleeding is an impressive trauma and the acute phase response results in a significant change in acute phase proteins. These changes arise quickly, the highest concentrations were achieved within the first 24 to $72 \mathrm{~h}$ and thereon they slowly declined.

Key words: acute phase proteins, hypovolaemic, shock, Wistar rats, whole blood

\section{INTRODUCTION}

Tissue trauma causes significant tissue injury no matter if they are mechanical, thermal or surgical. Such tissue trauma trigger mechanisms that lead to dysfunction of thermoregulation, fever in absence of infection, changes in homeostasis, rapid synthesis of acute phase proteins in the liver, muscle destruction with a negative nitrogen balance and hyperglycemia (Wolfe et al., 
1982; Clark et al., 1984). Such metabolic status represents the syndrome of systemic inflammatory response (SIRS) (Beal and Cerra, 1994). If the development of the acute response to trauma is unfavorable, SIRS leads to multiple organ dysfunction (MODS) and dysfunction of the organ systems. Usually, such syndrome is fatal (Nyström, 1998).

The main role of the acute phase response is to stop further and even greater damage of the injured tissue along with the activation of healing mechanisms. Concentration increase of acute phase proteins: $C$ - reactive protein, $2-\alpha$ macroblobulin, haptoglobulin, and fibrinogen and decreasing of the concentration of albumins and prealbumin (Hiyama et al., 1991) during the acute phase response, show that there is a connection between the site of tissue injury and the liver (Moshage, 1997; Jeschkte et al., 2004).

During inflammatory stage, liver cells rapidly produce acute phase proteins and such a phenomenon represents an adaptive response to inflammation. However, the precise role of the acute phase proteins is still not elucidated totally.

Whatever the cause of bleeding, there is a need for a prompt reaction of the organism in order to maintain tissue, and organ perfusion. The best way to treat bleeding is to remove the cause as soon as possible. The final goal is hemostasis, as well as blood volume replacement in an animal hospital. The prehospital phase is the time before definitive bleeding treatment. The extent of that phase has great influence on the intensity of bleeding. During bleeding in order to maintain homeostasis, various compensatory physiological mechanisms are activated. Exhaustion of these mechanisms causes specific and less specific patophysiological reactions. One of such reactions is the acute phase response.

It is clear that literature data on acute phase proteins during and after bleeding are still scarce, with the exception of those relative to the coagulation factors (fibrinogen) which is linked to post hemorrhagic coagulopathies (Fries et al., 2005; Scalea, 2011). Bleeding and injuries which result in hypovolemic shock are not primarily connected to inflammation; hence the link to acute phase proteins is not obvious. Acute phase proteins are listed as positive if their concentration increases during inflammation (fibrinogen, haptoglobin, $\alpha-2$ macroglobulin, C-reactive protein, complement factors, monozin binding protein) and negative if their concentration decreases (albumin, transferin, retinol binding protein), thus it was supposed that bleeding in the acute phase response can result in changes in protein concentration regardless of the fact that it is not primarily linked to inflammation.

The up to now used experimental models for uncontrolled bleeding (Kim et al., 1997; Marshall et al.,1997; Kim et al.,1998; Takasu et al.,1999; Soucy et al., 1999) were not adequate to sustain our statements as they resulted in high mortality. To the majority of authors a good survival of rats after bleeding was not indispensable and most often they removed the tail up to $50-75 \%$. After such treatment the rats would die within a day. For experimental purposes a model which would ensure survival during the following 10 days was needed. In such a way, acute phase proteins could be measured during the period of reconvalescence. 
In order to confirm this statement during a 10 day period we monitored the changes in negative (albumins) and positive acute phase proteins: fibrinogen, $\alpha-2$ macroglobulin and haptoglobin, as well as $\beta-1$ globulin i $\gamma$-globulin in rats' blood plasma. The animals were exposed to controlled bleeding. The effect of blood transfusion on the acute phase response was studied on rats which during the hospital phase received a transfusion of citrate blood. After the experiment the rats were monitored for further 10 days.

\section{MATERIAL AND METHODS}

Wistar adult male rats, 5-7 months old, body weight $400-700 \mathrm{gr}$ have been used for the trial. During the experiment the animals were kept in a stabile environmental and microclimatic surrounding, temperature $18-22^{\circ} \mathrm{C}$ with $22 /$ hour air replacements. Food and water were ad libitum. Animals were kept according to good laboratory and animal husbandry practice, obeying legislative rules that cover laboratory animal housing (Official Bulletin, 1998).

Before the beginning of the experiment, animals were grouped on a random basis. The control group (CG) consisted of 20 animals and in the treated group that received blood transfusion (BG) there where 12 animals. Rats were anesthetized intraperitoneally with Thiopental-sodium (Trepanal, BYK Gulden), $40 \mathrm{mg} / \mathrm{kg}$ of body weight. After the animals were anesthetized, each animal received a femoral artery and femoral vein I.V. catheter $(22 \mathrm{G} \times 0.8 \times 25 \mathrm{~mm})$ in order to measure blood pressure and to replace the lost blood volume. During the procedure the difference in the weight of the cotton swab (dry and blood soaked) was measured in order to calculate blood loss (1 mL is equivalent to $1.05 \mathrm{~g}$ ) and consecutive replacement of blood volume. Then, the tail of each animal was cut and the proximal segment was soaked in heparin. Blood was collected in measuring tubes.

\section{Method of tail amputation}

In order to standardize and to have less lethal outcomes for the procedure of rat tail amputation 100 rats were used. It was found that if 25 percent (measuring from the tip of the tail) of the rats' tail is cut, and if the proximal part of the tail is soaked in heparin for 30 minutes, this results in 20 to 25 percent loss of total blood volume. The estimated volume of blood is 5 percent of the rats' body mass. Such reduction of blood volume caused a reduction of the mean arterial pressure (MAP) by 40 to 50 percent. In that way, it is possible to control the intensity of bleeding and mortality in the next ten days to not more than 25 percent. Blood was collected in measuring tubes in order to plan further total blood transfusions.

Thirty minutes after tail amputation, total blood volume loss was measured and a surgical procedure was done in order to stop the bleeding. From that time, continuous blood replacement started. The control group (CG) of animals did not receive blood replacement. Animals that received citrate blood in the same volume as the blood lost were placed in the BG group. The time required for the blood transfusion was the same as the bleeding time (30 minutes). The prehospital phase in this experiment ended after 30 minutes. 
After the pre-hospital phase was finished, the I.V. catheters were removed from the animal and final homeostasis took place. Sera that was used for the estimation of the total protein concentration was obtained by blood coagulation (20 minutes, $37^{\circ} \mathrm{C}$ ), centrifuged 15 minutes $\left(5000 \times \mathrm{g} \mathrm{MSE}\right.$, MISTRAL $\left.4,37^{\circ} \mathrm{C}\right)$. Total protein and albumin concentrations in the serum were determined automatically (ASTRA-8, Automated Stat/Routine Analysier, Beckman). Total protein concentration was determined by the biuret reaction. Albumin concentration was determined by the bromocresol-blue method.

In order to analyze the acute phase proteins in the blood, blood samples were collected before tail amputation, on the first, second, third, fifth, seventh and tenth day (orbital sinus puncture). Plasma for determination of acute phase proteins concentration was obtained by centrifuging the heparinized blood. Such plasma samples were kept at $-20^{\circ} \mathrm{C}$ until testing of acute phase proteins by gelelectrophoresis. Commercial "Biomidi" electrophoresis kit was used. Such test is widely used for blood serum protein electrophoresis and plasma electrophoresin on agarose gel (Midgel proteins kig "Biomidi", Tolouse - France) according to Laurell's method (1973). Midgel proteins commercial kit could be used in order to determine proteins in different body fluids using electrophoresis on agarose gel. Midgel electrophoresis can be used to separate six protein fractions: albumins, alfa1, alfa2, beta1, beta2 and gamma globulins. Inside the fast gamma zone, according to the manufacturer of the kit, this method can separate fibrinogen, as well.

Detection of the particular protein fraction is in correlation with the space under the curve. In order to compare the values, one should calculate the relative concentration (space) of the particular fraction comparing to the starting control value.

In order to determine the concentration of the $\mathrm{Hp}$ and alpha-2 MG, rocket immunoelectrophoresis method has been used. Monospecific antiserum for haptoglobin was diluted 20 times with trisorbate EDTA (TBE) buffer. Monospecific antiserum for alpha-2 MG was diluted 10 times in 1XTBE buffer. Commercial solution containing the specific antibody was diluted in $22 \mathrm{~mL} 1 /$ agarose at $60^{\circ} \mathrm{C}$ Calbiochem, Agaroze type M). Next, agarose gel was spread on a glass surface $(10 \times 10 \mathrm{~cm})$. For more details on $\mathrm{Hp}$ and alpha-2 MG determination see Kataranovski et al. (1999).

Statistical analysis of the results was performed according to the Statistica 5.0 program. Descriptive data for total protein concentration are presented as mean values \pm standard deviation. Comparison of the data on total protein concentration between groups was performed according to Student- $t$ test for small independent and dependent samples, as well as variance analysis and test of proportion of differences. Acute phase proteins were presented as changes in relative values (in percents). Comparison between groups was analyzed by proportion differences test. Statistical significance has been accepted at the level of $p<0.05$ whereas highly significant statistical differences were at the $p<0.001$ level. 
Acta Veterinaria (Beograd), Vol. 61, No. 4, 391-403, 2011.

RESULTS

The control group (CG) had a mortality rate higher than $20 \%(4 / 20)$ compared to the treated (BG) group of animals which underwent blood transfusion (1/12) (Table 1). One animal from each group died during the prehospital phase while 3 rats from the CG group died during the first and second day after the experiment. During the first and second day the animals moved less willingly, lied down more often, but ate and drank as usual. In both groups there were no obvious signs of inflammation at the site of the surgical incision.

Table 1. Mortality during the experiment

\begin{tabular}{|l|c|c|}
\hline Time & CG & BG \\
\hline \hline $0-30 \min$ & 1 & 1 \\
\hline $31-150 \min$ & 0 & 0 \\
\hline$>150$ min & 3 & 0 \\
\hline Mortality \% & $20(4 / 20)$ & $8.3(1 / 12)$ \\
\hline
\end{tabular}

Total protein concentration

In the pre-hospital and hospital stage of the experiment the concentration of total proteins was measured. A significantly lower concentration of total proteins was recorded in both groups during the stage of acute bleeding compared to the

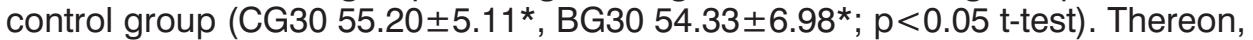
after final hemostasis and blood transfusion the protein concentration increased (CG150 56.12 \pm 6.16, BG150 57.75 \pm 6.17 ), but this increase was not statistically significant (Figure 1, Table 2).

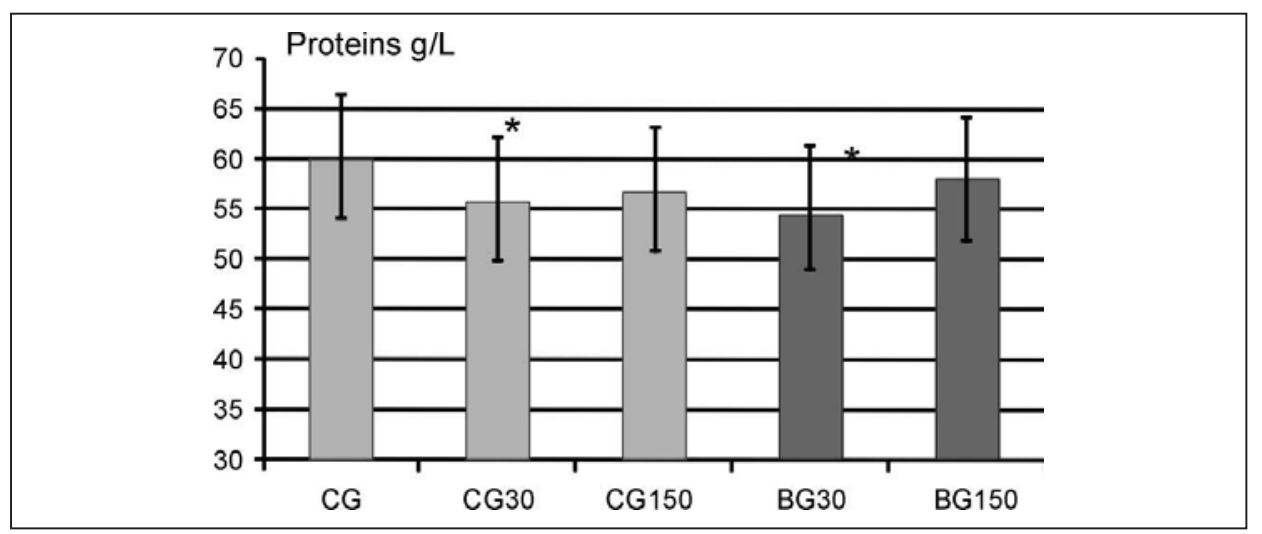

Figure 1. Total protein concentrations (mean $\pm \mathrm{SD}$ ) during the pre-hospital and hospital stage of the experiment $\left({ }^{*} \mathrm{p}<0.05\right)$ 
Table 2. Total blood protein concentrations

\begin{tabular}{|l|c|l|l|}
\hline \multirow{2}{*}{ Group } & \multirow{2}{*}{$\mathrm{n}$} & \multicolumn{2}{|c|}{ Proteins g/L } \\
\cline { 3 - 4 } & & Mean & $\mathrm{SD}$ \\
\hline \hline CG & 20 & 60.13 & 6.02 \\
\hline CG 30 & 20 & $55.20^{*}$ & 5.11 \\
\hline CG 150 & 20 & 56.12 & 6.16 \\
\hline BG 30 & 12 & $54.33^{*}$ & 6.98 \\
\hline BG 150 & 12 & 57.75 & 6.17 \\
\hline
\end{tabular}

${ }^{*} \mathrm{p}<0.05$ (t-test for independent sample)

Acute phase protein concentration

Table 3 represents data optained by measuring acute phase protein concentration (APP\%).

Table 3. Acute phase protein concentration (APP\%) measured 0, 1, 2, 3, 5, 7 and 10 th day of the experiment. ${ }^{*} p<0.05$ (test of the difference of proportions)

\begin{tabular}{|c|c|c|c|c|c|c|c|c|}
\hline \multirow[b]{2}{*}{ APP \% } & \multicolumn{8}{|c|}{ Time (day) } \\
\hline & Group & $\begin{array}{c}0 \\
\text { control }\end{array}$ & 1 & 2 & 3 & 5 & 7 & 10 \\
\hline \multirow{2}{*}{ Albumin } & $C G$ & 100.0 & 90.9 & 88.4 & 84.5 & 84.7 & 92.2 & 89.3 \\
\hline & $B G$ & 100.0 & 77.5 & $65.7 *$ & $68.1 *$ & $63.6 *$ & $64.6 *$ & $62.1^{*}$ \\
\hline \multirow{2}{*}{ Fibrinogen } & CG & 100.0 & 118.2 & 105.9 & 112.8 & 105.9 & 105.9 & 114.3 \\
\hline & $B G$ & 100.0 & $144.5^{\star}$ & $142.0 *$ & 132.2 & 127.8 & 127.8 & 130.3 \\
\hline \multirow{2}{*}{$\begin{array}{l}\alpha-2 \\
\text { macroglobulin }\end{array}$} & $C G$ & 100.0 & $234.4^{\star}$ & $260.9 *$ & $217.2^{\star}$ & $193.3^{*}$ & $147.5^{\star}$ & 127.0 \\
\hline & $B G$ & 100.0 & $264.3^{*}$ & $327.8 *$ & $347.0 *$ & $305.2^{*}$ & $276.5^{\star}$ & $248.7^{\star}$ \\
\hline \multirow{2}{*}{ Haptoglobin } & $\mathrm{CG}$ & 100.0 & $185.1 *$ & $370.3^{*}$ & $510.3^{*}$ & $275.6^{\star}$ & 90.2 & $40.8^{*}$ \\
\hline & $B G$ & 100.0 & $170.8 *$ & 290.4 * & $320.3^{*}$ & $150.6^{\star}$ & $215.4^{*}$ & $205.1 *$ \\
\hline \multirow{2}{*}{$\beta$-1-globulin } & CG & 100.0 & 118.2 & 105.9 & 112.8 & 105.9 & 105.9 & 114.3 \\
\hline & $B G$ & 100.0 & $144.5^{\star}$ & $142.0 *$ & 132.2 & 127.8 & 127.8 & 130.3 \\
\hline \multirow{2}{*}{$\gamma$-globulin } & $C G$ & 100.0 & $60.8 *$ & $62.2^{*}$ & $51.4^{\star}$ & $66.9 *$ & 73.6 & 99.3 \\
\hline & $B G$ & 100.0 & $64.6^{*}$ & $63.3^{*}$ & $54.9 *$ & $68.1 *$ & 99.1 & 123.5 \\
\hline
\end{tabular}

\section{Albumin concentration}

Changes in the relative albumin concentrations during the trial slowly decreased in both groups. The estimation on day $0(100 \%)$ is taken as the condition prior to the experiment. In such a way, each group was at the same time its own control. Values $<70 \%$ were considered as significant (BG2 65.7\%, BG3 $68.1 \%$, BG5 63.6\%, BG7 64.6\% and BG10 62.1\%; $p<0.05$ test of differences of 
proportions). In the BG group the decreased albumin concentration during the 10 day trial was significantly smaller compared to the initial value (Figure 2). In the CG group after the fifth day the concentration increased reaching at day seven $90 \%$ of the initial value. The differences between groups were significant from day 2 $(p<0.05)$.

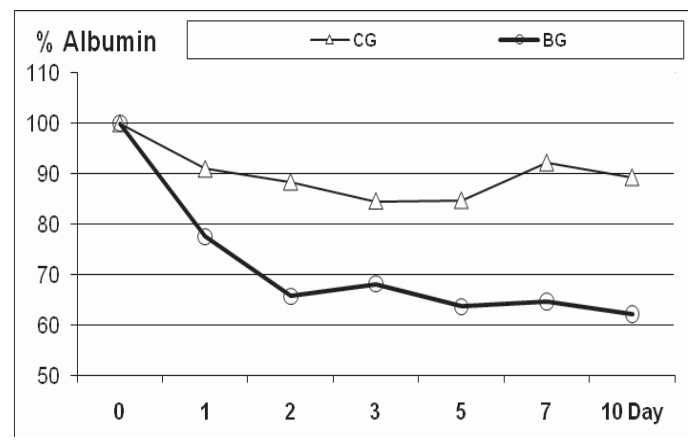

Figure 2. Changes in the relative albumin concentrations in rats' blood plasma after controlled bleeding without (CG) and with lost blood volume replacement (BG) expressed as \%

\section{Fibrinogen concentration}

The changes in the relative fibrinogen blood concentration in both groups manifested with increased values (Figure 3). The control (100\%) was for each group the starting value. Values $>140 \%$ were significant (BG1 $144.5 \%$, BG2 $142.0 \%, p<0.01)$. A statistically significant increase in blood fibrinogen concentration was recorded during the first and second day in the BG group after blood transfusion. The trend of increasing fibrinogen concentrations is maintained throughout the trial and is more evident in the BG group. The difference between treatments for day 2 and 3 is significant $(p<0.05)$.

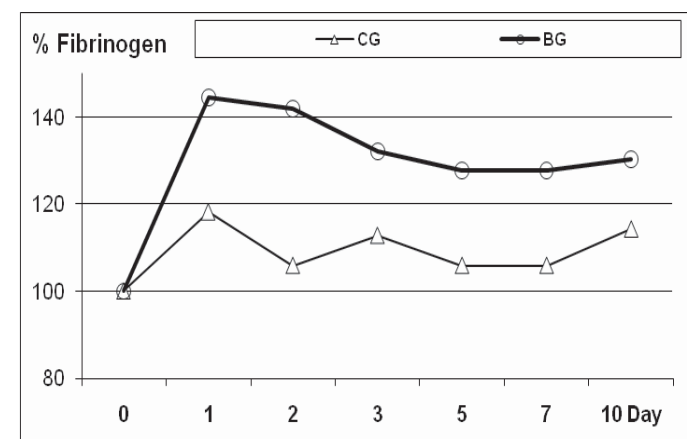

Figure 3. Changes in the relative fibrinogen concentration in the rats' blood plasma which underwent controlled bleeding without (CG) and with blood volume replenishment (BG) expressed as \% 
$\alpha-2$ macroglobulin concentration

In both groups as early as the first day of the experiment a statistically significant $(p<0.001)$ increase in the relative concentration of $\alpha-2$ macroglobulins was recorded (Figure 4). Values $>200 \%$ were considered significantly higher (CG1 234.4\%, CG2 260.9\%, CG3 217.2\%, p<0.001). The highest concentrations were measured on the second and third day after which they slowly decreased, but only in group $C G$ after 10 days reached the starting level. $\alpha-2$ macroglobulin concentration in group $B G$ was on the $10^{\text {th }}$ day significantly higher compared to the initial value (BG1 264.3\%, BG2 327.8\%, BG3 347.0\%, BG5 305.2\%, BG7 $276.5 \%$ and BG10 248.7\%, $\mathrm{p}<0.001$ ). The difference in the $\alpha-2$ macroglobulin concentration between groups was statistically significant from the second day of the trial up to the last day $(p<0.001)$.

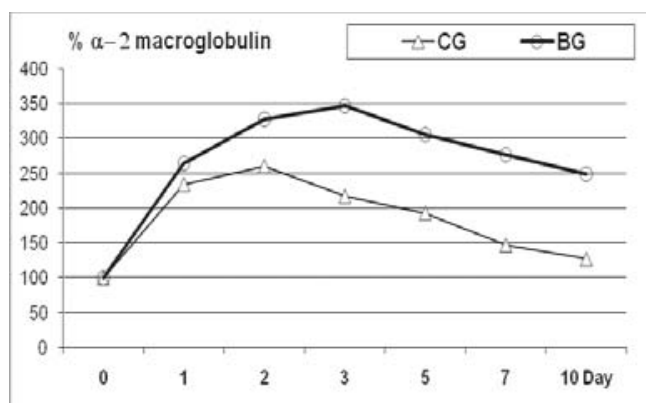

Figure 4. Changes in the relative $\alpha-2$ macroglobulin plasma concentrations after controlled bleeding without $(\mathrm{CG})$ and with lost blood volume transfusion replacement $(\mathrm{BG})$, expressed as \%

\section{Haptoglobin concentration}

After 24 hours both groups had a similar trend of increasing haptoglobin concentrations, similar to the trend for $\alpha-2$ macroglobulin (Figure 5).

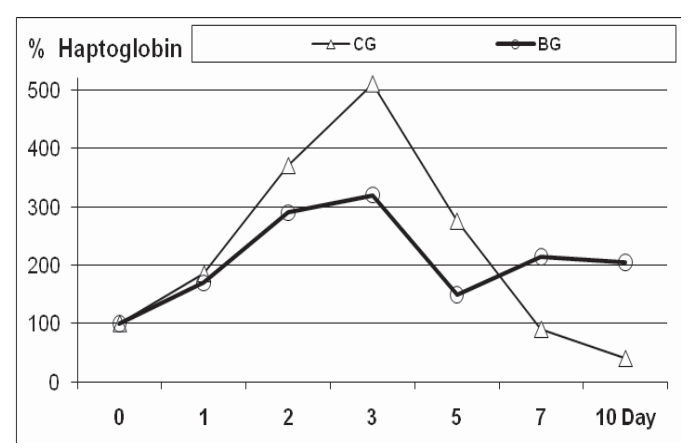

Figure 5. Changes in the relative haptoglobin plasma concentrations after controlled bleeding without (CG) and with lost blood volume transfusion replacement (BG), expressed as \% 
Values $>200 \%$ compared to the initial value are considered as significantly higher (CG2 370.3\%, CG3 510.3\%, CG5 275.6\%, p<0.001). After 24 hours both groups had a similar trend of increasing haptoglobin concentrations, similar to the trend for $\alpha-2$ macroglobulin (Figure 5). The maximum haptoglobin concentration was $3-5$ times higher than the initial value, and it occurred on the third day after ligation of the tail stumps. In the CG there was a sharp fall in haptoglobin concentrations between the $5^{\text {th }}$ and $10^{\text {th }}$ day (CG10 $40.8 \%$ of the initial value), while in the group which received a transfusion significantly higher values were maintained throughout the trial. The differences in haptoblobin concentrations were statistically significant between the two groups throughout the experiment $(p<0.001)$.

\section{$\beta-1$ globulin concentrations}

Beta globulins are a globulin fraction which includes $\beta-1$ and $\beta-2$ globulins.

In this paper changes in $\beta-1$ globulins, which include transferin and hematopexin, were measured. During the observation period $\beta-1$ globulin concentration increased in both groups. The slightly higher increase recorded in the transfused group was not statistically significant.

\section{$\gamma$-globulin concentration}

During the first five days alter bleeding $\gamma$-globulin concentration was significantly lower in both groups. After this period a permanent increase which was more evident for group BG was recorded (Figure 6 ). Values $<70 \%$ were significant (CG1 60.8\%, CG2 62.2\%, CG3 51.4\%, CG5 66.9\%, and BG1 64.6\%, BG263.3\%, BG3 54.9\% BG5 68.1\%; p<0.05).

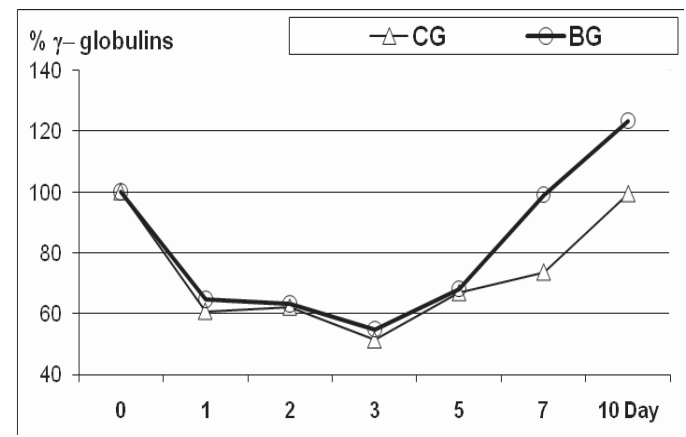

Figure 6. Changes in the relative $\gamma$-globulin plasma concentrations after controlled bleeding without (CG) and with lost blood volume transfusion replacement (BG)

\section{DISCUSSION}

In this study, changes in acute phase protein as part of the acute phase response as a result of controlled rat bleeding has been investigated. 
Haemorrhagiae, as well as bleeding, as a life threatening disorder is constantly of interest to scientists. There are lot of data on compensatory, as well as pathophisiological mechanisms, that were obtained using animal models controlled, as well as uncontrolled bleeding. This study shows that there is an important acute phase response that was mediated by a significant rise in acute phase proteins and reactants. Laboratory models of controlled bleeding are well known. They are reversible if blood transfusion with the same volume of complete blood or 3 to 4 times volume of crystalline salt dilution follows (Mapstone et al., 2003). The method of controlled bleeding that has been presented here has been described in materials and methods. Death rate (mortality) in the group of animals that did not receive blood replacement was 20 percent. Blood replacement caused all animals to survive (one animal died in BG group in the pre-hospital phase, before blood transfusion).

Results show that there is a significant rise in the concentration of positive acute phase proteins, as well as a decrease in the concentration of negative acute phase proteins (albumin). At the same time, there was a decrease in gamma globulin fraction in the post bleeding period.

Acute phase response is triggered by cytokines, especially IL-1, TNF, as well as IL-6 that mediate and connect the place of injury and the liver that is producing acute phase proteins (Gadient et al., 1999; Gruys et al., 2005; Wang and Ma, 2008; Herzum and Renz, 2008). Cytokines are products of various tissues and organs whereas interleukins are produced especially by leukocytes. Cytokines are produced by mammals, birds, reptiles, fish, even starfish (Petersen et al., 2004). This study shows that as a consequence of blood loss, there is loss of total blood proteins and decrease of albumin concentration. During bleeding, there is a decrease in concentration of all globulin fractions. Decrease of the albumin concentration, in such a case aims to maintain a normal (A:G) proportion even during decrease of total proteins.

Significant increase of positive acute phase protein concentration, caused by bleeding was of significant or moderate importance. Usually, main acute phase molecules concentration rise 10 to 100 times. Acute phase protein concentration rise of moderate importance is if it is 2 to 10 times. Less important are proteins which concentration rise is less that 2 times (Ceron et al., 2005). In rats, the main acute phase proteins are alpha-1 acid glicoprotein and alpha-2 macroglobulin. Moderately important are haptoglobulin, $\mathrm{C}$ reactive protein and fibrinogen (Schreiber et al., 1989).

Increased production of fibrinogen in the post bleeding period is the result of replacement of lost fibrinogen during bleeding. More intensive fibrinogen production in the group that received citrate blood is most probably the result of possible fibrinogen consumption during transfusion reaction.

Alpha-2 macroblobulin is a protein that can inactivate a number of proteases (serin, cistein, asparatate and metalloproteinases). Moreover, alpha-2 macroglobulin by acting on thrombin, acts as an inhibitor of blood coagulation. However, by blocking plasmin, it causes inhibition of fibrinolysis. Also, by doing that, it inhibits kalikrein, as well (de Boer et al., 1993). Significant rise in alpha-2 macroglobulin concentration after bleeding, especially in the group of animals 
that received citrate blood, makes this protein a part of the defense mechanism that blocks proteinase activity. By doing that, it stops degradation and loss of proteins in the case of injury. Coagulation inhibition stops post-traumatic coagulopathiae and basic protein concentration deficiency are the main cause of high morbidity and lethality due to tissue injury (White et al., 2010).

In the post hemorrhagic period the highest haptoglobin concentration increase of all acute phase proteins was measured. The major function of haptoglobin is to bind free plasma hemoglobin and transport it to the enzyme which breaks it down. The second not less important function is to stop the loss of iron through the kidneys and to protect the glomerules from blockage by hemoglobin (Wassell, 2000). The multiple increase was marked in the group which did not receive an infusion which shows that the high haptoglobin concentration is the answer to iron loss and acute anemia. Besides, haptoglobin is a protein which is synthesized not only in the liver, but in the skin, lungs and kidneys, also. The kidneys have a central role in the regulation of erythropoesis.

$\beta$-1-globulin consists of the iron binding transferin and hem binding hemopeksin thus saving iron in the organism. The change in $\beta$-1-globulin concentration is probably a reaction to the sudden anemia and it arises with the aim to stop serum iron loss. The decreased immunoglobulin concentration (IgM, $\lg G$, and $\lg A$ ) is the result of their loss during bleeding and slow activation of $B$ lymphocytes.

The results of this study confirm the supposition that bleeding is a heavy trauma and the acute phase manifests with a significant change in acute phase proteins. The changes in the acute phase proteins are swift and their peak concentrations occur in the first $24-72$ hours. Thereon their concentration decreases (phase reaction).

Monitoring of acute phase proteins after bleeding can be useful as a tool for health follow-up, and less useful as a diagnostic procedure in human and veterinary practice.

ACKNOWLEDGEMENTS:

This investigation was accomplished on Institute for medical research of Military Academy in Belgrade.

Address for correspondence:

Assoc. Prof. Dr. Predrag Stepanović

Faculty of Veterinary Medicine, University of Belgrade

Bulevar oslobođenja 18

11000 Belgrade, Serbia

E-mail: pedja@vet.bg.ac.rs

\section{REFERENCES}

1. Beal $A L$, Cerra FB, 1994, Multiple organ failure syndrome in the 1990s. Systemic inflammatory response and organ dysfunction, JAMA, 19, 271, 3, 226-33.

2. Clark AS, Kelly RA, Mitch WE, 1984, Systemic response to thermal injury in rats, Accelerated protein degradation and altered glucose utilization in muscle, $J$ Clin Invest, 74, 3, 888-97. 
3. de Boer JP, Creasey AA, Chang A, Abbink JJ, Roem D, Eerenberg AJ et al. 1993, Alpha-2macroglobulin functions as an inhibitor of fibrinolytic, clotting, and neutrophilic proteinases in sepsis: studies using a baboon model, Infect Immun, 61, 12, 5035-43.

4. Fries D, Krismer A, Klingler A, Streif W, Klima G, Wenzel V et al., 2005, Effect of fibrinogen on reversal of dilutional coagulopathy: a porcine model, J Anaesth, 95, 2, 172-7.

5. Gadient RA, Patterson PH, 1999, Leukemia inhibitory factor, Interleukin 6, and other cytokines using the GP130 transducing receptor: roles in inflammation and injury, Stem Cells, 17, 3, 127-37.

6. Gruys E, Toussaint MJ, Niewold TA, Koopmans SJ, 2005, Acute phase reaction and acute phase proteins, J Zhejiang Univ Sci B, 6, 11, 1045-56.

7. Herzum I, Renz H, 2008, Inflammatory markers in SIRS, sepsis and septic shock, Curr Med Chem, $15,6,581-7$.

8. Hiyama DT, von Allmen D, Rosenblum L, Ogle CK, Hasselgren PO, Fischer JE, 1991, Synthesis of albumin and acute-phase proteins in perfused liver after burn injury in rats, J Burn Care Rehabil, 12, 1-6.

9. Jeschke MG, Barrow RE, Herndon DN, 2004, Extended hypermetabolic response of the liver in severely burned pediatric patients, Arch Surg, 139, 641-7.

10. Kataranovski M, Magić Z, Pejnović N, 1999, Early inflammatory cytokine and acute phase protein response under the stress of thermal injury in rats, Physiol Res, 48, 6, 473-82.

11. Kim SH, Stezoski SW, Safar P, Capone A, Tisherman S, 1997, Hypothermia and minimal fluid resuscitation increase survival after uncontrolled hemorrhagic shock in rats, J Trauma, 42, 2, 213-22.

12. Kim SH, Stezoski SW, Safar P, Tisherman SA, 1998, Hypothermia, but not $100 \%$ oxygen breathing, prolongs survival time during lethal uncontrolled hemorrhagic shock in rats, J Trauma, 44, 3, 485-91.

13. Laure/l CB, 1973, Electroforesis, specific protein assays or both in measurement of pllasma proteins, Clin Chem, 19, 99-102.

14. Marshall HP Jr, Capone A, Courcoulas AP, Harbrecht BG, Billiar TR, Udekwu AO et al., 1997, Effects of hemodilution on long-term survival in an uncontrolled hemorrhagic shock model in rats, $J$ Trauma, 43, 4, 673-9.

15. Moshage $H$, 1997, Cytokines and the hepatic acute phase response, J. Pathol, 181, 257-66.

16. Nyström PO, 1998, The systemic inflammatory response syndrome: definitions and aetiology, $J$ Antimicrob Chemother, Jan, 41 Suppl A,1-7.

17. Petersen HH, Nielsen JP, Heegaard PM, 2005, Application of acute phase protein measurements in Ceron JJ, Eckersall PD, Martynez-Subiela S, Acute phase proteins in dogs and cats: current knowledge and future perspectives, Vet Clin Pathol, 34, 85-99.

18. Scalea TM, 2011, Hemostatic resuscitation for acute traumatic coagulopathy, Scand $J$ Trauma Resusc Emerg Med, 10, 19, 1, 2.

19. Schreiber G, Tsykin A, Aldred AR, Thomas T, Fung WP, Dickson PW et al., 1989, The acute phase response in the rodent, Ann N Y Acad Sci, 557, 61-85.

20. Soucy DM, Rude M, Hsia WC, Hagedorn FN, IIIner H, Shires GT, 1999, The effects of varying fluid volume and rate of resuscitation during uncontrolled hemorrhage, J Trauma, 46, 2, 209-15.

21. Takasu A, Carillo P, Stezoski SW, Safar PP, Tisherman SA, 1999, Mild or moderate hypothermia but not increased oxygen breathing prolongs survival during lethal uncontrolled hemorrrhagic shock in rats, with monitoring of visceral dysoxia, Crit Care Med, 27, 8,1557-64.

22. Upustvo za dobru laboratorijsku praksu, Službeni list SRJ, 1998, 40, 1-15.

23. Wang $H$, Ma S, 2008, The cytokine storm and factors determining the sequence and severity of organ dysfunction in multiple organ dysfunction syndrome, Am J Emerg Med, 26, 6, 711-5.

24. Wassell J, 2000, Haptoglobin: function and polymorphism, Clin Lab, 46 11-12, 547-52.

25. White NJ, Martin EJ, Brophy DF, Ward KR, 2010, Coagulopathy and traumatic shock: characterizing hemostatic function during the critical period prior to fluid resuscitation, Resuscitation 81,1 , 111-6.

26. Wolfe RR, Durkot MJ, Wolfe $M H, 1982$, Effect of thermal injury on energy metabolism, substrate kinetics, and hormonal concentrations, Circ Shock, 9, 4, 383-94. 
Acta Veterinaria (Beograd), Vol. 61, No. 4, 391-403, 2011.

Stepanović $\mathrm{P}$ et al.: Acute phase response

in Wistar rats after controlled hemorrhage

\section{ODGOVOR AKUTNE FAZE KOD WISTAR PACOVA POSLE KONTROLISANOG KRVARENJA}

STEPANOVIĆ P, MALIČEVIĆ Ž, ANDRIĆ N i NIKOLOVSKI STEFANOVIĆ ZORICA

\section{SADRŽAJ}

Odgovor akutne faze organizma na povredu tkiva aktivira mehanizme koji podrazumevaju oslobađanje citokina, hormona stresa, medijatora bola i zapaljenja. Njegova glavna funkcija je sprečavanje daljeg i većeg oštećenja povređenog tkiva uz aktivaciju reparatornih procesa. Porast koncentracije proteina akutne faze i smanjenje albumina i prealbumina ukazuje da postoji veza između mesta povrede i jetre. Smatrajući da je hemoragija teška povreda, pretpostavili smo da ona može izazvati promene u koncentraciji proteina akutne faze bez obzira što primarno nije povezana sa inflamatornom reakcijom.

U cilju dokazivanja ove pretpostavke tokom 10 dana su praćene promene „negativnih“ proteina akutne faze; albumina i „pozitivnih“; fibrinogena, $\alpha-2$ makroglobulina i haptoglobina, kao i $\beta$-1 globulina i $\gamma$-globulina u plazmi Wistar pacova koji su bili podvrgnuti kontrolisanom iskrvarenju.

$\mathrm{Za}$ potrebe ovog eksperimenta konstruisan je i novi model kontrolisanog krvarenja, koji je jedinkama omogućio preživljavanje tokom sledećih 10 dana, u toku kojih se merila promena relativnih koncentracija akutno-faznih proteina.

Ispitan je i uticaj terapijskog efekta transfuzije na stanje proteina akutne faze na grupi pacova koji su u tzv. „,hospitalnoj fazi” kao nadoknadu izgubljene krvi, dobili infuziju citrirane krvi. Po završetku eksperimenta nadgledano je opšte stanje životinja i praćen je letalitet tokom 10 dana. Rezultati našeg istraživanja potvrđuju pretpostavku da je krvarenje teška trauma za organizam pri čemu se odgovor akutne faze manifestuje značajnom promenom koncentracije odgovarajućih proteina, čije se maksimalne koncentracije registruju u prvih 24-72 časa nakon traume. 
